\title{
Community and Custom in Property
}

\section{Citation}

Henry E. Smith, Community and Custom in Property, 10 Theoretical Inquiries in Law 5(2009).

\section{Published Version}

doi:10.2202/1565-3404.1206

\section{Permanent link}

http://nrs.harvard.edu/urn-3:HUL.InstRepos:4555851

\section{Terms of Use}

This article was downloaded from Harvard University's DASH repository, and is made available under the terms and conditions applicable to Other Posted Material, as set forth at http:// nrs.harvard.edu/urn-3:HUL.InstRepos:dash.current.terms-of-use\#LAA

\section{Share Your Story}

The Harvard community has made this article openly available.

Please share how this access benefits you. Submit a story.

\section{Accessibility}




\section{Theoretical Inquiries in Law}

Volume 10, Number 1

January 2009

Article 2

COMMUNITY AND PROPERTY

Community and Custom in Property

Henry E. Smith*

Copyright (c)2008 The Berkeley Electronic Press. All rights reserved. 


\title{
Community and Custom in Property
}

\begin{abstract}
Henry E. Smith*
Community custom has played a limited but important role in the law of property. In addition to a few major historic examples such as mining camp rules and whaling, property law sometimes relies on community custom, for example in adverse possession, nuisance law, and beach access. This Article proposes an informational theory of custom in property law. Custom is subject to a communicative tradeoff in the law: all else being equal, informationally demanding customs require an audience with a high degree of common knowledge. General customs already known throughout society do not require much extra publicity from the law, and the law can easily draw on such customs. By contrast, customs that vary by community raise the question of the need for processing by non-expert audiences, i.e., outgroup dutyholders and government officials. This tradeoff helps explain the differential receptiveness to various customs and the process by which they are formalized if they are adopted into the law. The information-cost theory suggests that enthusiasts and skeptics of custom have both tended to ignore this process. The theory is then applied to some suggestive evidence from grazing customs and the pedis possessio doctrine in mining law, under which miners have pre-discovery rights to the spot being worked. Finally, the information-cost theory of custom sheds some light on the history and controversies over the numerus clausus (standardization and limitation of the set of basic property forms) and on the question of baselines of property entitlements in the law of takings.
\end{abstract}

* Fred A. Johnston Professor of Property and Environmental Law, Yale Law School. Email: henry.smith@yale.edu. For their helpful comments I thank Bob Ellickson, Dan Kelly, Carol Rose, David Schorr, and participants at a UCLA School of Law faculty workshop and the 2008 Property Works in Progress Conference at the University of Colorado Law School. In keeping with the widespread custom, all errors are mine. 


\section{INTRODUCTION}

Community custom has played a limited but important role in the law of property. In some well-known major historic examples such as mining camp rules and whaling, property law has adopted wholesale the customs developed by communities that stand in a special relationship to use conflicts. Although less common today, the law sometimes qualifies property rights through the recognition or adoption of customs, as in the case of beach access in some states. ${ }^{1}$ Less dramatically but more pervasively, law looks to custom to supply the content for notions like customary use as the standard for continuity in the law of adverse possession, ${ }^{2}$ the locality rule in the law of nuisance, ${ }^{3}$ and "ordinary wear and tear" in the law of waste. ${ }^{4}$

This Article proposes an informational theory of custom in property law. Custom is subject to a general communicative tradeoff: all else being equal, customs that are demanding from an informational standpoint require an audience with a high degree of common knowledge. ${ }^{5}$ General customs already known throughout society do not require much extra publicity from the law, and the law can easily draw on such customs. By contrast, legal enforcement of customs that vary by community may require processing by non-expert audiences, i.e., out-group duty-holders and government officials. This tradeoff helps explain when courts are (and are not) receptive to the incorporation of custom into the law, as well as the process whereby courts remove the need for contextual knowledge in the application and following

1 See, e.g., State of Oregon ex rel. Thornton v. Hay, 462 P.2d 671 (Or. 1969).

2 For an explicit acceptance of custom as the standard for use in adverse possession, see Nome 2000 v. Fagerstrom, 799 P.2d 304 (Alaska 1990). In other cases, customary use in terms of what is expected for the neighborhood is quite common. See, e.g., Howard v. Kunto, 477 P.2d 210 (1970) (seasonal use of vacation home suffices for continuity requirement in adverse possession).

3 See, e.g., Sturges v. Bridgman, 11 Ch. D. 852, 865 (1879); see also Robert C. Ellickson, Alternatives to Zoning: Covenants, Nuisance Rules, and Fines as Land Use Controls, 40 U. CHI. L. REV. 681, 728-33 (1973) (proposing nuisance liability for activities that are perceived to be "unneighborly under contemporary community standards").

4 Tenants are expected to return leased premises to landlords at the end of the leasehold in their initial condition, normal wear and tear excepted. See RESTATEMENT (SECOND) OF PROP.: LANDLORD AND TENANT § 12.2(3) (1977). In most applications, this can also be regarded as a contractual default, making the application of custom easier than in more impersonal contexts.

5 Henry E. Smith, The Language of Property: Form, Context, and Audience, 55 STAN L. REV. 1105 (2003). 
of custom. That is, in keeping with the informational tradeoff, courts exhibit a tendency to formalize custom in the course of adopting and adapting it for general application.

\section{The Debate over Custom in Law}

One perennial debate in legal theory centers around the relationship between custom and law. On the one hand, authors like Savigny, Blackstone, Hayek, and Epstein express an enthusiasm for custom, especially as a source for law. ${ }^{6}$ Sometimes this goes so far that lawyers and judges are regarded as passive recipients of this material in the process of its becoming law. ${ }^{7}$ Others, like Maine, Bentham, and modern legal centralists, see the law as something wholly distinct from custom and assign legal actors, especially legislators, the primary role in shaping the law. ${ }^{8}$ The polar positions are not the only possible ones, as Bruno Leoni points out. ${ }^{9}$ Leoni sees law as drawing and depending for its existence - on custom, but sees a role for lawyers and judges in generalizing and crystallizing custom into law. One aspect of this relationship is the formalization of custom - the stripping out of its dependence on community context — as it becomes general law.

6 William Blackstone, 1 Commentaries *63-92; Friedrich A. Hayek, New STUdies IN PHILOSOPHY, POLITICS, ECONOMICS AND THE History OF IDEAS (1978); FRIEDRICH A. HAYEK, LAW, LEGISLATION AND LIBERTY 46-47 (1973) [hereinafter HAYEK, LaW, LEgISLATION AND LibERTY]; Friedrich CARL Von SAVIGNY, Of THE VOCATION OF OUR AGE FOR LEGISLATION AND JURISPRUDENCE (Abraham Hayward trans., Arno Press 1975) (1814); Richard A. Epstein, International News Service v. Associated Press: Custom and Law as Sources of Property Rights in News, 78 VA. L. REV. 85, 101-02 (1992).

7 Others, like Robert Ellickson and to some extent Eugen Ehrlich, do not emphasize how the law incorporates custom but rather stress the role of custom as sometimes contradictory to but also often more important than law in everyday life. See EUGEN Ehrlich, Fundamental PRINCIPLES OF THE SOCIOLOGY OF LAW (W. Moll trans., Harvard Univ. Press 1936) (1913); ROBERT C. ElLICKSON, ORDER WithOUT LAW (1991). As mentioned earlier, I am focusing here on the transmission of norms from custom to law; $c f$. David Nelken, Eugen Ehrlich, Living Law, and Plural Legalities, 9 THEORETICAL INQUIRIES L. 443 (2008) (arguing that Ehrlich's living law captured the interdependence of official and unofficial law).

8 Jeremy Bentham, A COMMENT ON THE COMMENTARIES AND A Fragment ON Government (J.H. Burns \& H.L.A. Hart eds., 1931); JeREMY BENTHAM, THE TheOry OF Legislation 109-22 (C.K. Ogden ed., 1931); Henry Sumner Maine, ANCIENT LAW 1-20 (Transaction Publishers 2002) (3d ed. 1866).

9 BRUNO LeONI, FREEDOM AND THE LAW 216-18 (3d ed. 1991). 
Even writers like Blackstone can be regarded as treating nonlegal custom and the version implemented in the common law as being somewhat distinct. Indeed Blackstone is known for the greatest elaboration of a "test" for whether a custom should be adopted by judicial decision. This "test" is not always how courts approach custom, but it has been and continues to be an influential reference point. ${ }^{10}$ For Blackstone, a custom was a good candidate for incorporation into the common law if it satisfied the requirements of antiquity, continuity, peaceable use, certainty, reasonableness, compulsoriness (not by license), and consistency. ${ }^{11}$ Under the heading of certainty would come a lot of what I will be calling formalism, in the sense of non-context-dependence of information. ${ }^{12}$ Blackstone gives as examples of customs that would be too uncertain a rule that lands should descend to the most worthy of the owner's issue (as opposed to the next male) and a custom to pay in lieu of tithes either two or three pence, as the owner pleases (as opposed to simply two pence, or a year's improved value). ${ }^{13}$ The uncertain customs might not be so uncertain to a community member, but this would not make them candidates for adoption into the law.

Interestingly, various proponents of custom, like Savigny and Leoni, analogize law to language in explaining the role of custom and its evolution. ${ }^{14}$ Like language, custom bubbles up from practice and cannot be easily constructed from scratch (cf. Esperanto). Also, like language, custom evolves into various dialects. ${ }^{15}$ To this we might add that the sociolinguistic variation we see between community dialects and more general dialects (like Standard American English) have their analogies in custom and the law. In particular, the style of language used in communities versus larger groupings is characterized by lesser formalism (interpretation will vary more by context) in both language and the law. ${ }^{16}$ Greater informality and need for context can also help define and maintain group identity: only those in the know will

10 See, e.g., State of Oregon ex rel. Thornton v. Hay, 462 P.2d 671 (Or. 1969); J.H. Balfour Browne, The Law of Usages and Customs (S.S. Clarke ed., Jersey City, Frederick D. Linn \& Co. 1st Am. ed. 1881) (1875); John D. LaWson, THE LaW of Usages And Customs (St. Louis, F.H. Thomas \& Co. 1881).

11 Blackstone, 1 COMMENTARIES *76-78.

12 See Francis Heylighen, Advantages and Limitations of Formal Expression, 4 Found. SCI. 25, 49-53 (1999); Smith, supra note 5, at 1112-13.

13 Blackstone, 1 COMMENTARIES *78.

14 SAVigny, supra note 6, at 19; Friedrich CARL Von SAVIGny, System OF THE MODERn RomAN LAW 36-37 (William Holloway trans., 1980); see also LEONI, supra note 9, at 218; Anna di Robilant, Genealogies of Soft Law, 54 AM. J. CoMP. L. 499, 527-32 (2006).

15 BRownE, supra note 10, § 17, at 20-21.

16 See, e.g., Jean-Marc Dewaele, How to Measure Formality in Speech: A Model 
find it easy to employ community context in interpretation. In-group slang is based on this type of context-specific informality, with Leet or leetspeak on the Internet being one particularly prominent recent example. ${ }^{17}$

Judges are not the only filter between custom and the legal world. Interestingly it is another communicative act that has the tendency to strip out some contextual information: proving custom to a jury. It has been a long time since juries were self-informing, but jurors are still drawn from the community, in a broad geographic sense. Juries can be expected to be able to draw on some community background but, apart from the possibility of resurrecting merchant juries, lay jurors tend not to have the knowledge from special communities to which they do not belong. As sociolinguistic studies have shown, this type of cross-community communication is itself likely to result in a significant degree of formalization of custom. ${ }^{18}$ Thus, the need to communicate customs to those outside the community, including the judge and jury, ensures that putting customs into evidence is an additional process contributing to formalization. ${ }^{19}$

In a more modern vein, Friedrich Hayek's heavy reliance on custom has drawn the familiar criticism for naiveté, in particular for its exaggeration of the role of judges. ${ }^{20}$ But one of the more realistic aspects of the process that Hayek implicitly advocates is the partial formalization of preexisting custom. Hayek's enthusiasm for custom leads him away from the question of the interface between custom and more impersonal mechanisms. The price system, which he sees as a highly effective method for coordinating the rich but local and widely dispersed knowledge of ordinary economic actors, only works because it boils down a lot of information into a very formal format. It is true that an individual price may be embedded in the context of a transaction, but the information that travels as a signal is the price itself, divorced from

of Synchronic Variation, in APPROACHES TO SECOND LANGUAGE ACQUISITION 119 (Kari Sajavaara \& Courtney Fairweather eds., 1996).

17 See, e.g., Christopher Rhoads, What Did U \$@y? Online Language Finds Its Voice, WALL ST. J., Aug. 23, 2007, available at http://online.wsj.com/ article/SB118679550023894850.html; Leet, in WIKIPEDIA, http://en.wikipedia. org/wiki/Leet\#_note-4 (last visited May 1, 2008). Even the term "Leet" or "1337" (and other variants) originated from having "elite" status online.

18 The need for jurors to deliberate over custom may reinforce this effect, depending in part on the size of the jury and how many votes are required for a verdict.

19 The substantive requirements of certainty, uniformity, and notoriety also require certain types of testimony and forbid others. See BROWNE, supra note $10, \S 72$, at 117-25; id. at 120 n.6 (citing Cope v. Dodd, 13 Pa. 33 (1850)).

20 John Hasnas, Hayek, the Common Law, and Fluid Drive, 1 N.Y.U. J.L. \& LIBERTY 79 (2005). 
much of the context. In seeing in custom a similar mechanism for economizing on information, Hayek seemed to believe that in adopting customs to the common law judges would find what is generalizable in them and strip away the accidental. ${ }^{21}$ Thus, communication by prices in a market and adjudicating disputes through custom both require some generalization and abstraction away from particular contexts. Hayek is vague about what exactly judges do, and, as has been pointed out, he overlooked the frequent passivity of common-law judges and the role of the jury in using custom in common-law cases. ${ }^{22}$ More importantly from our point of view, it is not just the arbitrary aspects of custom that need to be shorn away but some of the contextual information that makes its burden on non-community members greater. This process is consistent with the Blackstonian filter and, as mentioned earlier, is not solely a function of judging. The process of proving a custom to a jury of non-community members is likely to have a similar effect.

Critics of a role for custom in law see it as too uncertain and eclectic. On this view, for custom to be usable at all, legislators or judges must do most of the essential work, at the end of which custom-based law would be no different from other law. ${ }^{23}$ In particular, the traditional requirement that a custom be reasonable calls upon judges to make substantive decisions and puts the process on a path towards no special role for custom. ${ }^{24}$ Descriptively it is the case that the common law relies less on custom than it once did, and this trend has only been reinforced by the positive and normative claims of positivists (including in this respect the Legal Realists) that law gets its force from a rule of recognition, which leaves little room for custom to operate

21 HAYEK, LAW, LEGISLATION AND LiBERTY, supra note 6, at 72-74.

22 Hasnas, supra note 20, at 100. By contrast, Richard Posner criticizes Hayek for assuming that the process of adopting custom as law required excessive passivity of judges. See Richard A. Posner, Hayek, Law, and Cognition, 1 N.Y.U. J.L. \& LIBERTY 147, 150 (2005). Hayek viewed judges, like any other candidate for central planner, as unable to gather and use the information required for engineering correct rules in the fashion Posner assumes. See Todd J. Zywicki \& Anthony B. Sanders, Posner, Hayek, and the Economic Analysis of Law, 93 IowA L. REV. 559 (2008).

23 See, e.g., John Austin, The Province of Jurisprudence Determined 30-32 (Noonday 1954) (1832) ("[B]efore [a custom] is adopted by the courts, and clothed with the legal sanction, it is merely a rule of positive morality."); Richard Craswell, Do Trade Customs Exist?, in THE JURISPRUDENTIAL FOUNDATIONS OF CORPORATE AND CoMmerCial Law 132 (Jody S. Kraus \& Steven D. Walt eds., 2000) (arguing that trade customs do not make an independent substantive contribution in cases ostensibly involving custom).

24 James Q. Whitman, Why Did the Revolutionary Lawyers Confuse Custom and Reason?, 58 U. CHI. L. REV. 1321 (1991). 
as law on its own. ${ }^{25}$ Indeed, on this view, the rule of recognition is the only custom needed. And although a rule of recognition could theoretically point to custom, positivists wind up emphasizing the contribution of judges and legislators in determining the content of the law. ${ }^{26}$ Positivists and other legal centralists also make a corresponding normative claim, that custom on its own lacks legitimacy and bears no guarantee of suitability for anyone other than its generators. ${ }^{27}$ Although proponents of the efficiency of social norms do not always claim that customs will be efficient or desirable outside close-knit groups of origin, the centralist skeptics are more likely to see custom as the product of oppression within such groups. Thus, normatively, in order to apply customs to those outside the group of origin we need some filter to prevent illegitimate customs from spreading. For example, while mining customs became part of general mining law, some norms in the mining camps were explicitly discriminatory and, if adopted as law, would have been unconstitutional, especially by today's lights. ${ }^{28}$ But the centralists go farther: the process of filtering is not distinguished from starting from scratch, and the

25 See George Rutherglen, Custom and Usage as Action Under Color of State Law: An Essay on the Forgotten Terms of Section 1983, 89 VA. L. REV. 925 (2003).

26 Id. at 960; see also H.L.A. HART, THE CONCEPT OF LAW 44-49, 100-10 (2d ed. 1994). On the compatibility of Legal Realism and Legal Positivism, see Brian Leiter, Legal Realism and Legal Positivism Reconsidered, 111 ETHICs 278 (2001).

27 See, e.g., Morton J. Horwitz, The Transformation of AmERICAN LAW, 18791960: THE CRISIS OF LEGAL ORTHODOXY 211-12 (1992) (arguing that in fashioning the Uniform Commercial Code, Karl Llewellyn "endowed economically dominant commercial practices with undeserved normativity").

28 See, e.g., Gavin Wright \& Karen Clay, Order Without Law: Property Rights During the California Gold Rush, 42 EXPLORATIONS ECON. Hist. 155, 169 (2005); see also David E. Bernstein, Lochner, Parity, and the Chinese Laundry Cases, 41 WM. \& MARY L. REV. 211 (1999) (discussing state anti-Chinese legislation and its invalidation by Lochner-era federal courts on Fourteenth Amendment grounds); Thomas Wuil Joo, New "Conspiracy Theory" of the Fourteenth Amendment: Nineteenth Century Chinese Civil Rights Cases and the Development of Substantive Due Process Jurisprudence, 29 U.S.F. L. REV. 353 (1995) (arguing that the motivation for federal courts to strike down anti-Chinese legislation was the desire to protect economic liberty under the Fourteenth Amendment). The homogeneity of the miners' culture probably made developing and enforcing norms easier, using common cultural focal points, but the exclusionary aspect had its dark and violent side as well. See Andrea G. McDowell, From Commons to Claims: Property Rights in the California Gold Rush, 14 YALE J.L. \& HuMAN. 1 (2002); Richard O. Zerbe, Jr. \& C. Leigh Anderson, Culture and Fairness in the Development of Institutions in the California Gold Fields, 61 J. ECON. HIST. 114 (2001). The appropriateness of custom for outsiders depends in part on the content of the custom and the extent to which it legitimately constitutes the group, and these issues sometimes arise under the reasonableness test for custom. Carol Rose, The Comedy of the Commons: 
emphasis is on the active role of the judge or legislator at the center. Indeed custom, like other traditions, can be seen by the centralists as an inconvenient obstacle to centralized rational social engineering.

The information-cost theory suggests that both the proponents and opponents of adopting custom into law have been hasty at times. Proponents need to be more sensitive to the informational burden placed on duty-holders who are farther removed from the community that originated a custom. Adoption into law is likely to increase that burden and some formalization of the custom may be required as part of the adoption process. Indeed, law's lesser dependence on custom now as compared to centuries past reflects in part the need for standardization appropriate to a large market economy and a diverse polity. ${ }^{29}$ Opponents of community custom in the law tend to accuse its proponents of mixing categories and not understanding the differences between custom and law. But if custom tends to be formalized in the process of its adoption into law, the resulting legal rule need not be that different in character from other legal rules. It remains an empirical question whether judges or other decisionmakers can make better legal rules by stripping some of the information content out of custom, than they would by eschewing custom altogether.

I will argue that the eclectic quality of custom-based law that offends the centralists is sometimes the byproduct of this process of formalization. Also, the process of formalizing a custom to make it more appropriate for wider audiences partially allays concerns that custom in the law has not received the proper consent from those it governs. Judges adopting Blackstonian or other criteria for custom can benefit from the dispersed information possessed by communities, but the legal rule need not present as large an imposition on non-community members as critics fear.

\section{Communicating Community Custom}

The role of custom or social norms has attracted much attention from legal scholars and some economists. Perhaps the most revolutionary aspect of the study of social norms is the recognition that norms can serve as a substitute for law, and can even thrive in the face of contrary law. ${ }^{30}$ The

Custom, Commerce, and Inherently Public Property, 53 U. CHI. L. Rev. 711, 769 (1986).

29 On the tension, both historical and theoretical, between custom and standardization, see infra Section IV.A.

30 ELLICKSON, supra note 7, at 4-6. 
importance of custom in everyday life is a counterweight to legal centralism, the view that governments (especially nonlocal governments) are the main source of rules of conduct. ${ }^{31}$ Nevertheless, there have been famous episodes, such as mining law, in which the law has adopted or adapted customary rules for use in common-law adjudication and occasionally incorporated custom into statutes. In other situations, local custom has been rejected outright as a source of law. ${ }^{32}$

This Article will explore the question of when law incorporates the custom of particular communities into the general law of property and the informational constraints on this process. These constraints hold in all communicative systems, but, in the case of custom, communities tend to be both its authors and its audiences. From the point of view of the law, custom is easiest to apply in its own context; it is when the audience expands beyond originating communities that the tradeoff between an information-rich custom and the size and heterogeneity of the audience must be restruck.

Previous literature has not primarily focused on the information costs to which customs give rise. ${ }^{33}$ In the literature on social norms, it is theorized that

31 Id. at 138-40; see also Talia Fisher, Nomos Without Narrative, 9 THEORETICAL INQUIRIES L. 473 (2008); John Hasnas, The Depoliticization of Law, 9 THEORETICAL INQUIRIES L. 529, 534-41 (2008); Oliver E. Williamson, Credible Commitments: Using Hostages to Support Exchange, 73 AM. ECON. ReV. 519, 520, 537 (1983).

32 Courts vary in this regard, but interestingly courts that reject custom tend to disparage custom as a source of law rather than get into the merits of which rule is better. One procedural explanation for this phenomenon is that the role of custom is often couched in terms of whether evidence on the custom is admissible or not. In such cases, custom is not allowed to trump general rules of law. For example, in Fisher v. Steward, 1 Smith 60 (N.H. 1804), the court declared:

It has been said, that, by the usage of this part of the State, the person who finds bees acquires a property in them wherever found. We recognize no such usage. We have no local customs or usages which are binding in one part of the State and not in another. If this be the law here, it must be so in every other part of the State.

33 An exception is the growing awareness that outsider British colonists tended to discount customary rights that did not fit into an English law mold. See, e.g., WILlIAM CRONON, CHANGES IN THE LAND: INDIANS, COLONISTS, AND THE ECOLOGY of New England 58-81 (1983); Stuart Banner, Two Properties, One Land: Law and Space in Nineteenth-Century New Zealand, 24 LAW \& Soc. INQUIRY 807, 811-12 (1999). Also, the complexity of local custom in common property regimes is difficult for outsiders to understand and therefore not easily susceptible to trading on a market. Carol M. Rose, Expanding the Choices for the Global Commons: Comparing Newfangled Tradable Allowance Schemes to Old-Fashioned Common Property Regime, 10 DuKE ENVTL. L. \& POL'y F. 45, 63-66 (1999) (discussing how 
norms that emerge in a close-knit community have a tendency to be efficient for the community members, but not necessarily for society at large. ${ }^{34}$ Coercion within the group and various group dynamics can prevent community norms from being ideal in the sense of efficient or fair. Here I will focus on the relations of communities and their customs to wider social groups. Like individuals and business organizations, communities can create externalities too. We can question the fairness of holding an actor bound by a custom she may not have consented to.

Efficiency and fairness in the narrow sense of the "correctness" of an allocation rule does not completely exhaust the concerns raised by the spread of custom beyond its immediate social environment in a community. Additionally, custom makes informational demands on those who are expected to abide by it and on those who are to enforce it. Consider the example of marking sites for surgery to avoid the disturbingly common problem of wrong-site surgery. ${ }^{35}$ Marking the correct limb (right or left) using "Yes" or initials or marking the wrong side with an "X" or red sock seem equally efficient and fair, but it turns out that for the semi-initiated, the red sock requires the least background knowledge and is the easiest to transmit to doctors who may not be closely linked into the network or community (such as a hospital) devising the system. (For a surgeon not on the lookout for a "Yes" the wrong limb can easily be mistaken for the correct one.) One can imagine a newsletter informing the medical community in a city, state, or nation that a "Yes" is a necessary condition for surgery, but this would require extra communication cost: more information must be transmitted, as compared to "No" or the red sock.

common property regimes "can be very complex and can baffle outsiders entirely," making them difficult to trade); see also James Salzman \& J.B. Ruhl, Currencies and the Commodification of Environmental Law, 53 STAN. L. REV. 607 (2000) (exploring the tension between nonfungibilities of environmental commodities and their tradability). In our terms, markets are an extensive context calling for reduced information intensiveness along a variety of dimensions. See Smith, supra note 5, at 1189; see also supra notes 15-16 and accompanying text.

34 ELLICKSON, supra note 7, at 167-83.

35 Jennifer Steinhauer, So, the Brain Tumor's on the Left, Right? Seeking Ways to Reduce Mix-Ups in the Operating Room, N.Y. TIMES, Apr. 1, 2001, at A23; Agency for Healthcare Research and Quality, Making Health Care Safer: A Critical Analysis of Patient Safety Practices, ch. 43.2: Strategies to Avoid Wrong-Site Surgery (July 2001), available at http://www.ahrq.gov/clinic/ptsafety/chap43b.htm; see also Smith, supra note 5, at 1138-39; James W. Saxton \& Maggie M. Finkelstein, Can Adhesive Labels Prevent Wrong Site Surgery and Reduce Liability Risk?, 12 WIDENER L. REV. 293 (2005). 
Informational demands increase with the social distance from the creators of the custom. In the medical context, we worry about the new doctor in a hospital. In previous work I argued that law is subject to this type of informational tradeoff, which is characteristic of human communication in general: at the same cost one can either communicate in an intense way with a specific, close audience with common knowledge, or in a more stripped-down, formal way with a more extensive audience. Within the law, contract and property strike this tradeoff differently. In contract, the primary audiences for contractual duties are close to the deal, either as participants or, with slightly more distance, as third-party beneficiaries. Correspondingly, contract law largely allows parties to create their own customs in the course of dealing, and even devise their own idiosyncratic language. ${ }^{36}$ This is true both of the common law of contract and the Uniform Commercial Code. ${ }^{37}$ In general, realists and formalists have argued about the extent to which context is relevant for contractual interpretation, but overall more context is considered relevant in interpreting contracts than in the case of property. ${ }^{38}$ Property, by contrast, is much more formal in the sense that it relies less on context and imposes a greater degree of standardization, most notably in the doctrine that property comes in a closed set of basic forms (or "building blocks"), i.e., the numerus clausus. ${ }^{39}$ In both contract and property, third-party adjudicators must be able to figure out what is going on, but the informational needs of judges to some extent track those of primary audiences, and judges do seem to have some intuition about the informational tradeoff.

This fundamental difference between contract and property makes sense in terms of both the costs and benefits of communication in the two areas. ${ }^{40}$ In contracts a smaller and more definite set of actors needs to process the deal, but the stakes are quite high and concentrated on them. The nature of the deal is largely irrelevant to third parties. And in those situations in which third parties do get involved - in the tort of interference with contract, assignments, and

36 Smith, supra note 5, at 1148-57, 1177-90.

37 See, e.g., U.C.C. § 1-201(a) (2004) ("Unless the context otherwise requires, words or phrases defined in this section, or in the additional definitions contained in other articles of [the Uniform Commercial Code] that apply to particular articles or parts thereof, have the meanings stated."); id. § 2-202 (course of performance and parole or extrinsic evidence).

38 Smith, supra note 5, at 1177-90.

39 Thomas W. Merrill \& Henry E. Smith, Optimal Standardization in the Law of Property: The Numerus Clausus Principle, 110 YALE L.J. 1 (2000); Smith, supra note 5 , at $1148-57$

40 Smith, supra note 5, at 1148-67; Henry E. Smith, Modularity in Contracts: Boilerplate and Information Flow, 104 MICH. L. REV. 1175, 1207-14 (2006). 
third-party beneficiaries - contract law becomes more formal, in the sense I am using here of less context-dependent ${ }^{41}$ Property requires different actions and forbearance from a wide set of parties. In those aspects of property that communicate the in rem right to the "rest of the world," the audience is as wide and indefinite as it can be, but the contribution that far-flung parties make consists largely of keeping off.

The various strategies used to delineate and enforce property rights reflect the basic communicative tradeoff. If property is characterized by an initial use of an exclusion strategy to deal with the basic delegation of decision-making authority to owners and the prevention of basic theft in the interest of protecting stability of expectations and autonomy, then the message is a simple one that need not rely much on contextual information. ${ }^{42}$ However, sometimes the stakes increase and we get a shift to governance - rules targeting use conflicts more directly. ${ }^{43}$ This can take the form of exceptions to the right to exclude or additional rules of proper use. These rules start to get more informationally demanding and the law rations them more closely and seems to reflect the need to keep the message to far-flung parties within a reasonable cost. It is one thing to require neighbors to abide by community norms, quite another to expect a stranger to know and abide by them. A default license to hunt might well make sense in an area in which many people hunt, but requiring a potential stranger hunting a wild animal to know when it is still subject to capture raises a more difficult informational question. ${ }^{44}$

One large difference between the exclusion and governance strategies is the heavier reliance of the former on modularity. Social and legal relations are part of a complex system, and one method for managing complexity is modularity. ${ }^{45} \mathrm{~A}$ system is partially decomposable if parts of the system

41 Merrill \& Smith, supra note 39, at 54-55 (assignments); Smith, supra note 5, at 1186-87 (third-party beneficiaries); id. at $1166 \&$ n.215 (tortious interference).

42 Henry E. Smith, Exclusion Versus Governance: Two Strategies for Delineating Property Rights, 31 J. LeGAL STUD. S453 (2002).

43 Id.; Henry E. Smith, Exclusion and Property Rules in the Law of Nuisance, 90 VA. L. REV. 965, 1021-45 (2004).

44 This particular problem is familiar in property from the famous case of Pierson $v$. Post, 3 Cai. 175 (N.Y. Sup. Ct. 1805). On the communicative aspect of the case, see Carol M. Rose, Possession as the Origin of Property, 52 U. CHI. L. REV. 73, 78, 85 (1985); Smith, supra note 5, at 1117-19.

45 Herbert A. Simon, The Sciences of the Artificial (2d ed. 1981); see also MOdularity IN DEVElopMENT AND Evolution (Gerhard Schlosser \& Günter P. Wagner eds., 2004); Lauren W. Ancel \& Walter Fontana, Plasticity, Evolvability, and Modularity in RNA, 288 J. EXPERIMENTAL ZOOLOGY 242 (2000); Günter P. Wagner \& Lee Altenberg, Complex Adaptations and the Evolution of Evolvability, 
can be identified within which interaction is dense and strong but between which it is less dense and weaker. If so, these components can be treated as modules such that modules only interact through interfaces. Other internal information is hidden; hiding information allows activity within modules to occur in partial isolation. The contribution the module makes to the working of the whole system becomes more predictable. Modular systems are often more resistant to shocks because damage can be contained with a module. Likewise modular systems can evolve more easily through the modification or substitution of individual modules without causing ripple effects through the entire system. In software, for example, modular structure is employed in order to make program complexity easier to manage; parts of the software combine in more predictable ways and decisions about one aspect will not ripple out of control. ${ }^{46}$ If there is a common print-function that can be called upon in certain standard ways, substituting a new print-function will cause manageable change to the overall program. Likewise the teams that create modular artifacts like software take advantage of modularity ${ }^{47}$ With little or no modularity, complexity can spiral out of control.

The exclusion strategy in property benefits from modularity. First, by giving the owner a right to exclude, many use questions are delegated to that owner. ${ }^{48}$ Information about the uses of the asset and the features of the owner are largely, thought not completely, irrelevant to outsiders. If I walk through a parking lot, I know not to take cars and I need not know who the cars belong to - whether it is a person or a corporation - the age or income or moral worthiness of the owner, or whether the car is on loan to a friend. ${ }^{49}$ I need only know that it is not mine and to keep off. Likewise the remedy for theft does not make any inquiry into these features of the owner. Limited exceptions are made for high-stakes situations in which bargaining is not feasible, such as

50 Evolution 967 (1996); John J. Welch \& David Waxman, Modularity and the Cost of Complexity, 57 Evolution 1723 (2003).

46 Object oriented programming in particular employs modularity. See, e.g., GRADY BOOCH, OBJECT-ORIENTED ANALYSIS AND DESIGN (1994); EdWARD YOURDON, OBJECT-ORIENTED SYSTEM DESIGN: AN INTEGRATED APPROACH (1994).

47 See, e.g., Carliss Y. Baldwin \& Kim B. Clark, Design Rules: The Power of MODULARITY 6-11, 169-94 (2000).

48 Henry E. Smith, Property and Property Rules, N.Y.U. L. REV. 1719, 1758-64 (2004); Smith, supra note 43, at 1021-45.

49 See J.E. Penner, The Idea of Property in Law 29-30, 71 (1997); Thomas W. Merrill \& Henry E. Smith, What Happened to Property in Law and Economics?, 101 YALE L.J. 357, 359 (2001); Smith, supra note 5, at 1151; Smith, supra note 42, at $\mathrm{S} 475$. 
necessity. ${ }^{50}$ Evaluation of context becomes more important here - mostly context about the person in need. If the one facing necessity - for example, the need to flee an assailant — had to endanger the life of the owner, then necessity would not apply. More systematically, areas of the law like nuisance make more information about uses and users relevant, including the utility of the activity, the hypersensitivity of the plaintiff, etc. ${ }^{51}$ This is a more elaborate interface. Governance between adjacent private property owners can be thought of as part of the interface between property modules. In the case of common property, governance rules are internal to large modules, with reliance on the exclusion strategy to send messages about duties of abstention to non-group members outside the module. In common property, the property module keeps all but a large group out but uses internal governance rules to guide the behavior of the large group that does have access.

As the example of common property suggests, human groupings like communities can be regarded as modules. Organization theorists have employed modularity to explain the structure of certain organizations, especially those that produce modular products like computer software and hardware.$^{52}$ In this Article, I will apply these ideas to communities and show how community boundaries function as modules and serve as an important way station from the smaller, closer-knit audiences that can engage in intensive communication to more extensive audiences beyond the community.

Interestingly, in the vast literature on modularity an important subbranch applies the concept of modularity to community. Sociologists and

50 See, e.g., Ploof v. Putnam, 71 A. 188 (Vt. 1908).

51 William L. Prosser, Handbook of the LaW of Torts $\S 89$, at 596-602 (4th ed. 1971) (considering the "reasonable use" balancing test and citing modern case applications). Under the Second Restatement, a nuisance is a substantial nontrespassory invasion of use and enjoyment of land that is caused either by intentional and unreasonable activities, or negligent, reckless, or ultrahazardous activities. RestaTEMENT (SECOND) OF TORTS $\S \S 821 \mathrm{~F}, 822$, 826-28 (1979); 6A AMERICAN LAW OF PROPERTY § 28.22, at 66, § 28.26, at 75-77 (A. James Casner ed., 1954) (emphasizing the vagaries associated with, and importance of, a determination as to whether a defendant's conduct is unreasonable); 1 FOWLER V. HARPER \& Fleming JAMES, JR., THE LAW OF TORTS $§ 1.24$, at 70-74 (1956) (discussing the importance of reasonableness considerations in nuisance cases). See generally Jeff L. Lewin, Boomer and the American Law of Nuisance, 54 ALB. L. REV. 189, 212-14 (documenting the limited adoption of the balance of the utilities test for reasonableness, and citing cases); Smith, supra note 43.

52 See BALdWIN \& ClARK, supra note 47; MANAGING IN THE MOdUlaR Age: Architectures, Networks And Organizations (Raghu Garud, Arun Kumaraswamy \& Richard N. Langlois eds., 2003); Richard N. Langlois, Modularity in Technology and Organization, 49 J. ECON. BEHAV. \& ORG. 19 (2002). 
sociolinguists have used network theory to study the diffusion of information and patterns of communication. ${ }^{53}$ Theorists have used algorithms for finding modules to discover "communities" through the identification of groups with dense and strong ties that are only weakly connected to the world outside. ${ }^{54}$ For our purposes, this application of network theory allows the communicative tradeoff to be more precise and testable in principle. Basically, we expect $a$ correlation of formalism with distance from a community. The relevant notion of distance here is social distance as captured in part by the length of the path between the speaker and the audience and the weakness of the links in that path. ${ }^{55}$ Thus, with long-distance communications and especially the Internet one can be socially close to physically distant people, although the importance of shared implicit knowledge and sometimes physical proximity that supports it are easily overlooked. ${ }^{56}$

Examples of such a tradeoff in communication more generally have been established. ${ }^{57}$ Other studies are consistent with this tradeoff, including Mark Granovetter's work on "weak ties. ${ }^{58}$ Granovetter provides suggestive evidence for a hypothesis framed in terms of network theory: messages travel long social distances, modeled by long path length, through weak ties. Strong ties are characterized by spending a large amount of time together, emotional intensity, intimacy and reciprocity, and the strength of a tie between two persons is predicted to correlate with the overlap of their social networks. Communities are characterized by strong internal ties and weaker ties to the outside. To this picture we might add that the communication along the weak ties from one community to another tends to be "formal" as befits weak ties,

53 See, e.g., Lesley Milroy, Language And Social Networks 139-44 (1980); James Milroy \& Lesley Milroy, Mechanisms of Change in Urban Dialects: The Role of Class, Social Network and Gender, in 1 THE SOCIOLINGUISTICS READER: Multilingualism AND VARiation 179 (Peter Trudgill \& Jenny Cheshire eds., 1998).

54 See, e.g., Aaron Clauset, M.E.J. Newman \& Christopher Moore, Finding Community Structure in Very Large Networks, 70 PHYS. ReV. E 70, 066111 (2004); M.E.J. Newman, Modularity and Community Structure in Networks, 103 PROC. NATL. ACAD. SCI. USA 8577 (2006).

55 Social distance may but need not correlate with geographic and temporal distance.

56 See, e.g., John SeEly Brown \& PAul Duguid, The Social Life of Information 11-33, 167-70, 223-31 (2002) (arguing for the importance of non-explicit knowledge in the information age and the importance of social distance).

57 See, e.g., Dewaele, supra note 16.

58 Mark S. Granovetter, The Strength of Weak Ties, 78 AM. J. Soc. 1360 (1973); see also Mark Granovetter, Economic Action and Social Structure: The Problem of Embeddedness, 91 AM. J. Soc. 481 (1985). 
in which intensity of interaction and common knowledge cannot be as easily assumed. Communities thus have a modular structure, and the formal tools used to study the nature of modules have been applied to the detection of communities in networks.

This use of network theory makes it possible to formalize the notions of information intensity and audience extensiveness. In previous work I began to show that this communicative tradeoff operates in the law and is why judges and other legal decision-makers might be inclined in the direction of more formalism in less intimate contexts. ${ }^{59}$ Here I am suggesting that distance from a community center can be a relevant measure of extensiveness for purposes of the communicative tradeoff.

Formalism here simply means relative invariance to context. This definition can be used to capture many instances of formalism: thus mathematical formalism is more invariant to context in its interpretation than are other forms of communication. ${ }^{60}$ In the hospital example above, some of the forms of communicating which side to operate on, like using initials, are less formal than "yes" or "no" or the red sock because they require more background knowledge and attention to context; they are less formal than the sock in particular. According to the communicative tradeoff, we should expect messages to tend to become more formal as they leave the confines of the community of origin. Either the communication must become more stripped down in order not to overload the more extensive audience, or more processing costs will have to be incurred. This could include educating the more extensive audience with the relevant background knowledge, or it could involve informing them about the particular customary rule at issue.

The ease of incorporating community custom into the law is determined in part by this basic communicative tradeoff, and the informational tradeoff is reflected in the limited portability of custom. At a very gross level, the greater receptiveness to contract customs than property customs is a striking example of this: contract is more open to the use of industry custom because the relevant set of duty-holders is closer to the deal than is the case in many in rem property situations. But within property itself, some customs are better candidates for generalization than others. In addition to questions about efficiency and fairness, community customs make different informational demands on wider audiences. As I will show, the communicative tradeoff allows us to derive a number of subsidiary propositions about the adoption or adaptation of community custom into the law.

59 See Smith, supra note 5; Smith, supra note 40.

60 See sources cited in supra note 12. 
1. Community-Internal Custom: Custom that impacts only community members is easier to incorporate into property law than equivalent customs that would require processing by third parties. In both contracts and property there is a familiar related issue: custom should be known or at least reasonably knowable to those who are bound by it. The communicative tradeoff points to another aspect of this problem that has to do with the format of information. Even if we are inclined to enforce a custom, we have a choice whether to enforce the version of it prevalent within the community, which is intense from an informational standpoint, or to use the law to pare out aspects of relevant context. This can be regarded as one aspect of identifying a custom, a process that is far from trivial, as Richard Craswell has argued. ${ }^{61}$ If experts testify to the application of a custom to a given situation, they are typically giving the crystallized result of a more implicit and intuitive exercise of judgment. ${ }^{62}$ The communicative tradeoff points to the need to choose the informational strategy - including the degree of invariance to context (i.e., formalism) — that the custom will exhibit as applied in a legal context. Among the outsiders who have to process custom are the legal enforcers. Thus, to take the example of the medieval grazing commons, the community itself or a court very close to the community would enforce the stints and other rules of proper grazing. ${ }^{63}$ There was little need to simplify or formalize customs in such a context. ${ }^{64}$ All the participants, including the enforcers, were on the same page. Indeed we find in many of the successful common-property institutions, such as those studied by Ostrom, Rose, and Acheson, that the participants themselves are enforcers. ${ }^{65}$ Likewise, in merchant courts and arbitration within associations there may be a preference for bright-line rules or standards depending on the context (for example, mid-game versus endgame), but there is less reason to formalize custom in the sense of creating

61 Craswell, supra note 23.

62 Craswell employs the semantics-pragmatics distinction to argue that customs can carry different types of information in varying contexts. Id. at 129-35.

63 See, e.g., W.O. Ault, OPEn-Field Farming In Medieval England: A Study of VILlage By-Laws 123, 137, 141 (1972) (stinting of sheep); ErIC Kerridge, THE COMMON FIELDS OF ENGLAND 77 (1992) (same).

$64 C f$. Ault, supra note 63, at 53-54 (hypothesizing that the lack of early written rules or case records on encroachment by planting on a neighboring furrow can be explained by the obviousness of the rule in a close-knit community).

65 See, e.g., Elinor OSTROM, Governing THE COMMONS (1990); Rose, supra note 28; James M. Acheson, Management of Common-Property Resources, in ECONOMIC ANTHROPOLOGY 351 (Stuart Plattner ed., 1989). 
invariance to context. ${ }^{66}$ Both enforcers and duty-holders share the background information to make intensive communication cost-effective.

2. Formalization of General Custom: The flip side of the ease of communicating intensively within a community is the need to strike a different communicative tradeoff as custom applies more widely. One major method of re-striking the tradeoff is to formalize the custom, i.e., to decrease the dependence on context and hence its variance across contexts. Partly because enforcers will be in a similar position to non-community duty-holders and partly perhaps because this communicative tradeoff is an ingrained part of our cognition, in the process of using custom as the basis for more widely applicable legal rules judges and other legal decision-makers will decrease the context-dependence of community custom as it travels out of the community of origin to wider audiences. There will be a tendency to make a custom more formal and standardized in the process of applying it more widely (if it is so applied). We can hypothesize that in most cases it is easier to communicate an exception to the right to exclude rather than a norm of proper use, since the latter typically depends on contextual information. Using exceptions to the right to exclude to solve problems across community boundaries is easier than trying to communicate rules of proper use. Thus, in cases in which strangers, rather than neighbors, are involved we expect a tendency to loosen the right to exclude rather than to adopt complex balancing tests that might require a great deal of contextualized knowledge. Further, limiting custom that binds strangers to these simple rules can make the result of judicial adoption of the custom more predictable to those who will be bound by it. ${ }^{67}$ One example of this is the hunting custom: the default license to hunt on unenclosed land is an exception to the right to exclude, whereas first possession customs involving wild animals can be seen as closer to rules regulating activities.

3. Employment of Common Knowledge and Salience: Formalism is not

66 See, e.g., Lisa Bernstein, Opting Out of the Legal System: Extralegal Contractual Relations in the Diamond Industry, 21 J. LEGAL STUD. 115 (1992); Lisa Bernstein, Merchant Law in a Merchant Court: Rethinking the Code's Search for Immanent Business Norms, 144 U. PA. L. ReV. 1765 (1996); Lisa Bernstein, Private Commercial Law in the Cotton Industry: Creating Cooperation Through Rules, Norms, and Institutions, 99 MiCH. L. REV. 1724 (2001).

67 The efficiency and fairness of making a custom binding for the first time raises related systemic and individual issues. From the systemic point of view, both the custom and its legal force should be predictable. From an individual point of view, a party may be aware of the custom even though actors in a similar situation would not be. In such cases I would hypothesize that courts would turn to equity which is both in personam and heavily reliant on notice. 
the only way for a custom that is escaping its originating community to reflect the communicative tradeoff. If the custom happens to depend on knowledge shared more widely than only in the community of origin or can easily be refashioned to do so, then the custom is a good candidate for wider use, at least as far as the informational load it presents. One particularly common strategy is to rely on salience, wherever salience comes from. ${ }^{68}$ Salience in some instances may reflect hard-wired aspects of mind, as where judgments of closeness and lesser-goes-with-greater arguably drive the law of accession. ${ }^{69}$ We say that increments of value such as the young of an animal go with the owner of the mother for a mixture of utilitarian and psychological reasons. ${ }^{70}$ In other cases, such as the famous experiment in which most people independently chose to meet at Grand Central Station at noon, some type of widely shared common knowledge is doing the work. ${ }^{71}$ As we will see, parts of property law that regulate the behavior of anonymous interaction tend to rely on these general sources of context. Thus, nearness is easier to employ than notions of likelihood of capture when hunters and non-hunters might encounter each other in the presence of a fox. We should tend to find more incorporation of community custom where the custom relies on knowledge likely to be found outside the community or relies on salience and focal points that do not require intense interaction by the parties.

4. Impact of Higher Stakes: Another response to the possibility of a custom traveling beyond its community of origin is simply to incur the higher communication costs of making broader audiences responsible for observing it. This can happen where the problem involves high stakes and communicatively cheaper alternatives are not available. ${ }^{72}$ Higher stakes

68 See Richard H. McAdams, A Focal Point Theory of Expressive Law, 86 VA. L. REV. 1649, 1659-63 (2000).

69 David Hume, A Treatise of Human Nature 327 (David Fate Norton \& Mary J. Norton eds., Oxford Univ. Press 2000) (1739); Thomas W. MerriLl \& Henry E. Smith, Property: Principles and Policies 172-75 (2007); Robert Sugden, The ECONOMICS OF Rights, Co-OPERATION \& Welfare 87-88, 97-99 (1986); Thomas W. Merrill, Establishing Ownership: First Possession and Accession (2008) (unpublished manuscript, on file with author).

70 Carruth v. Easterling, 150 So.2d 852, 855 (Miss. 1963) (quoting 4 AM. JUR. 2D Animals § 10). See generally Merrill, supra note 69.

71 Thomas C. Schelling, The Strategy of Conflict 55-56 (1963); see also id. at 97; Judith Mehta, Chris Starmer \& Robert Sugden, The Nature of Salience: An Experimental Investigation of Pure Coordination Games, 84 AM. ECON. REV. 658 (1994); Robert Sugden, A Theory of Focal Points, 105 Econ. J. 533 (1995).

72 Higher stakes can make incurring more communication costs worthwhile. See Smith, supra note 5, at 1155; Smith, supra note 43, at 966-997, 1007. The anti-formalism of the Legal Realists and their successors can be regarded sympathetically as a 
lead to greater presumption of widespread common knowledge and a greater tendency for custom to travel beyond the originating community. The whaling custom that required people finding harpooned finback whales washed up on the beach to report them (and receive a finder's fee instead of the whale itself) seems to have bound people in the whaling community of Provincetown, not just the whalers themselves. ${ }^{73}$ A one-industry town can afford to make such informational demands.

$* * *$

In sum, I hypothesize that custom reflects a basic tradeoff in legal communication. Custom is informationally intense only so long as it is directed at a smaller, more expert audience. As it becomes more propertylike, in order to spread the custom must either draw on existing common knowledge or it must be radically simplified. Only in cases of particularly high stakes would we expect informational burdens to be placed on far-flung audiences of duty-holders.

Overall, intensive communication is easier within communities but becomes more costly with greater distance from the community. As with the exclusion strategy itself, the community can be regarded as a module in an overall social and communicative system. Intensive communicative custom is cheaper within such communities than across community boundaries. And for some purposes it is useful if third parties can treat the community as a black box. If outsiders are not held responsible for knowing community custom or only a formalized version of it, much information can be hidden behind the interface between the community in question and the rest of the world.

\section{Community Custom in Property LaW}

The use of custom in property is less free than in contract and varies according to the type of property context. If property at its core uses an exclusion strategy for anonymous interactions and refines this basic setup through governance strategies in more contract-like settings, we expect that

response to the higher stakes of use conflict and other problems, or, less charitably, as a fallacious disregard of information costs, or perhaps more realistically, as some of both.

73 Ghen v. Rich, 8 F. 159 (D. Mass. 1881). On the efficiency of the substance of the rule, see Robert C. Ellickson, A Hypothesis of Wealth-Maximizing Norms: Evidence from the Whaling Industry, 5 J.L. ECON. \& ORG. 83, 93 (1989). 
the use of custom should track this distinction. Particularized customs that require a great deal of community background knowledge should be used in those more personalized property contexts in which governance rules are used. Where property relies on the exclusion strategy we expect less reliance on localized customs, through either non-adoption or formalization in the process of being incorporated into the law. In this Part I will show that community custom is subject to the communicative tradeoff and that the law reflects a concern with the informational demands of custom when it travels beyond its originating community. As expected, custom, if enforced at all outside the community, is more formal the farther it is from the community. I turn now to some applications of the information-cost theory of community custom. Some of these examples are open to multiple interpretations. They are meant as suggestive and illustrative of the propositions that can be derived from the theory.

Perhaps the most familiar example of community custom in property law revolves around norms of proper use in common property. Here the property boundary and the community boundary largely coincide: the community are the owners and have the right collectively to exclude the rest of the world. Inside the boundary communities have often successfully instituted governance regimes to solve the potential tragedy of the commons. Indeed the grazing commons is often not tragic for precisely this reason, making Hardin's use of it as an illustration of "The Tragedy of the Commons" particularly inapt. ${ }^{74}$

The law of co-ownership can be regarded as a mini-version of this community common property. Anglo-American property law tends to take a love-it-or-leave-it approach, based on partition and using the "exit" strategy. Hanoch Dagan and Michael Heller, inspired by civil law, would like to see a greater effort by the legal system to promote cooperative behavior without giving up on the right to exit. ${ }^{75}$ This liberal commons, in its reliance on governance, does make informational demands on co-owners. But as long

74 See sources cited in supra note 65; Garrett Hardin, The Tragedy of the Commons, 162 SCIENCE 1243 (1968). However, Hardin popularized the treatment in the academic literature. See H.S. Gordon, The Economic Theory of a Common Property Resource: The Fishery, 62 J. Pol. Econ. 124 (1954); Jens Warming, Om "Grundrente" af Fiskegrunde, 49 NATIONALÖKONOMISK TIDSSKRIFT 495 (1911), translated in P. Anderson, "On Rent of Fishing Grounds": A Translation of Jens Warming's 1911 Article, with an Introduction, 15 HIST. POL. ECON. 391 (1983); Jens Warming, Aalgaardsretten, 69 NATIONALÖKONOMISK TIDSSKRIFT 151 (1931).

75 Hanoch Dagan \& Michael A. Heller, The Liberal Commons, 110 YALE L.J. 549 (2001). 
as this informational problem is confined to the co-owners and does not lead to potential liability for third parties, the property module prevents extensive audiences from bearing large information costs.

More generally, institutions in the borderland between property and contract pose interesting cases of the informational tradeoff. Merrill and I have argued that intermediate areas like landlord-tenant, trusts, security interests, and bailments tend to reflect an intermediate degree of intervention, through enhanced notice requirements or protection (often from liability) for the third party. ${ }^{76}$ In other words, the law tries to reduce the informational load on more remote third parties. Sometimes these intermediate cases intersect with relevant communities. While trade custom is familiar from contract law, property law takes a somewhat warier view of corresponding community customs.

Take for example the customs surrounding good husbandry in agricultural leases. As I have shown in previous work, the law differentiated as to when manure should be used on the land on which the producing animals grazed. ${ }^{77}$ In an agricultural lease, in which the tenant is part of the relevant community of farmers, one might assume knowledge of this aspect of good husbandry. ${ }^{78}$ By contrast, manure is assimilated to general personal property when it comes to the question of whether, on the death of the owner, it should come into the hands of the executor as personal property or go with the land directly to the heir. ${ }^{79}$ Intermediate between these two situations are mortgage and sale cases, in which the lender or buyer may well have more knowledge of agricultural practice than an executor but not as much as a farmer. Here most but not all courts held that the manure goes with the land ${ }^{80}$ Notice that the farther we get from the community the more general notions of personal property kick

76 Thomas W. Merrill \& Henry E. Smith, The Property/Contract Interface, 101 CoLuM. L. REV. 773, 843-49 (2001).

77 Smith, supra note 5, at 1122-25.

78 Generally in an agricultural lease the default was that the lessee must use on the land manure produced by animals grazing on that land. See, e.g., Lassell v. Reed, 6 Me. 222 (1829); Daniels v. Pond, 38 Mass. (21 Pick.) 367 (1838); Middlebrook v. Corwin, 15 Wend. 169 (N.Y. 1836); Hill v. De Rochemont, 48 N.H. 87 (1868); Lewis v. Jones, $17 \mathrm{~Pa} .262$ (1851).

79 Pinkham v. Gear, 3 N.H. 484 (1826); 2 Tiffany ON ReAl Property $§ 629$ (3d ed. 1939). But see Fay v. Muzzey, 79 Mass. (13 Gray) 53 (1859).

80 On mortgages, see, for example, Perry v. Carr, 44 N.H. 118 (1862); Sawyer v. Twiss, 26 N.H. 345 (1853). But see Staples v. Emery, 7 Me. 201 (1831). On sales, see, for example, Kittredge v. Woods, 3 N.H. 503 (1826); Goodrich v. Jones, 2 Hill 142 (N.Y. 1841). But see Ruckman v. Outwater, 28 N.J. 581 (1860). 
in. If the question is enforcement against a nonmember of a community, then manure is likely to be treated as free-floating personal property.

This tendency for the default to work in the direction of generality and formalism is quite characteristic of the intersection of custom and property law. Consider for example the famous issue of fencing in and fencing out. ${ }^{81}$ It is well known that the law varies between fencing in and fencing out, and that this choice correlates with whether ranching or farming is more prevalent in an area. ${ }^{82}$ Robert Ellickson in his study of Shasta County found that social norms were nonetheless uniform, in that they made animal owners responsible for crop damage, regardless of the law. ${ }^{83}$ One possible interpretation is that the message to keep off, the default regime of possession, is easier to communicate to more far-flung parties ${ }^{84}$ Consistent with this, Ellickson notes that there has been an influx of ranchette owners who are not insiders to the culture of the area. The general, formal default - here the norms of trespass and exclusion - have a gravitational pull, beyond the benefits in terms of the relative importance of farming compared to ranching. Even where a more nuanced flip of the rule from fencing in to fencing out would be efficient in the narrow sense of maximizing the value of the two activities, in close cases there is an additional reason to stick with the general rule of fencing in, because it comes along with the general exclusion regime for ownership of land, which is undemanding from an informational standpoint. Only when the narrow efficiency advantage of fencing out becomes large does it make sense to move to fencing out. Although we are not in a position to identify the exact point of optimality, there is some suggestive evidence in favor of the prediction that in both law and norms fencing in will be more widespread than would be expected on a narrow efficiency account.

Sometimes common-law judges are explicit about their concerns with the informational load of particular customs applying to a more extensive set of duty-holders. Whaling is an area in which robust customs were developed in the industry and by and large adopted by common-law courts in legal disputes over the ownership of whales. Ellickson argues that these customs were efficient for whalers who formed a close-knit group of repeat players. ${ }^{85}$ The customs varied by type of whale in a way that made sense: for faster and

81 ELLICKSON, supra note 7, at 52-53, 72-76; Merrill \& Smith, supra note 49, at 388-94; Smith, supra note 5, at 1116-17.

82 See, e.g., Kenneth R. Vogel, The Coase Theorem and California Animal Trespass Law, 16 J. LeGAL STUD. 149, 152 (1987).

83 ELLICKSON, supra note 7, at 52-53, 72-76.

84 Merrill \& Smith, supra note 49, at 388-94; Smith, supra note 5, at 1116-17.

85 Ellickson, supra note 73. 
meaner whales custom (and later the common law) would not require whalers to maintain a line to the ship for first possession. Ellickson takes whaling customs as confirmation of the hypothesis that close-knit groups will devise norms that are efficient for the group, but not necessarily for society or the world as a whole. (Indeed the customs were good at allocating whales but not at all effective at conserving them and avoiding a tragedy of the commons.) Nevertheless, as we will see, courts in dealing with whaling cases are quite clear about their reservations about particular customs displacing general rules of the common law.

We can also hypothesize that even as between whalers, general norms of possession may have had some stickiness. Thus, the fast-fish-loose-fish rule seems to be the "default rule"; the rule that the first harpooner has the possession of the whale as long as the harpoon is connected by a line to the boat looks more like general notions of possession based on certain control than the more special first-iron rule. Under this latter rule the first harpooner had an exclusive right to the whale as long as he was in fresh pursuit; the first-iron rule made sense for sperm whales which were both the most valuable and the most dangerous. But even courts willing to adopt whaling customs express reservations not just with binding non-consenting strangers — as well they might — but with letting special rules leak out and confuse the general law of possession. In Swift v. Gifford, ${ }^{86}$ Judge Lowell adopts the first-iron rule despite its derogation from the general law of possession. The court addressed this problem directly:

The rule of law invoked in this case is one of very limited application. The whale fishery is the only branch of industry of any importance in which it is likely to be much used; and if a usage is found to prevail generally in that business, it will not be open to the objection that it is likely to disturb the general understanding of mankind by the interposition of an arbitrary exception. Then the application of the rule of law itself is very difficult, and the necessity for greater precision is apparent. ${ }^{87}$

In response to arguments that the custom would "overturn[] a plain and well-settled rule of property," 88 the court did note an increasing reluctance to adopt particular customs and quoted as typical Justice Story's observation in

8623 F. Cas. 558, 559 (D. Mass. 1872) (No. 13,696).

87 Id. at $559-60$.

$88 \quad I d$. at 559. 
The Reeside ${ }^{89}$ a contracts case in which he sat as Circuit Justice for the United States Court of Appeals for the First Circuit:

I own myself no friend to the almost indiscriminate habit of late years, of setting up particular usages or customs in almost all kinds of business and trade, to control, vary, or annul the general liabilities of parties under the common law, as well as under the commercial law. It has long appeared to me, that there is no small danger in admitting such loose and inconclusive usages and customs, often unknown to particular parties, and always liable to great misunderstandings and misinterpretations and abuses, to outweigh the well-known and well-settled principles of law. ${ }^{90}$

Judge Lowell does not take this as dispositive because, again, the custom was confined to the community of whalers from a particular port (probably specializing in a certain type of whale). Moreover, Story's statement can be interpreted as a plea for respecting the communicative tradeoff: use of particular customs which puts an informational burden on duty-holders and enforcers - and one that grows as the distance between them and the originating community increases. Again, in the property classic Ghen v. Rich a custom of reporting beached finback whales that have been killed with a marked bomb lance in return for a finder's fee was upheld as applying to the finder, because it was of limited application and could "affect but a few persons,"91 and, quoting Judge Lowell, was "not open to the objection that it is likely to disturb the general understanding of mankind by the interposition of an arbitrary exception."92

By contrast, in somewhat less high-stakes cases the tendency to adopt custom is weaker. Agricultural areas vary in terms of whether the finder or the locus owner becomes the owner of an un-owned swarm of bees that alight on a tree (and their honey). In Fisher v. Steward,$^{93}$ the court rejects evidence of local custom that would have favored the finder and instead applies general notions of trespass and makes a strong pronouncement on uniformity:

It has been said, that, by the usage of this part of the State, the person who finds bees acquires a property in them wherever found.

8920 F. Cas. 458, 459 (C.C.D. Mass. 1837) (No. 11,657).

$90 I d$. at 459. For a discussion of a variety of judicial pronouncements for and against use of trade customs, see LAWSON, supra note 10, $\S 4-5$.

91 Ghen v. Rich, 8 F. 159, 162 (D. Mass. 1881).

92 Id. (quoting Swift v. Gifford, 23 F. Cas. 558, 559-60 (D. Mass. 1872) (No. 13,696)).

931 Smith 60 (N.H. 1804). 
We recognize no such usage. We have no local customs or usages which are binding in one part of the State and not in another. If this be the law here, it must be so in every other part of the State. ${ }^{94}$

While this may be an overstatement, it does reflect an understandable policy of formalism for extensive audiences.

Other famous episodes of adoption of custom into the law also involve formalization of the relevant custom. Mining law is a potential testing ground, although I leave development of this application of the informationcost theory for further work. As mining customs, both with respect to mining claims and water rights, were taken up into the common law and adopted through state and federal statutes, some of the contextual factors that would have been readily understood by mining camp participants were stripped out. Much recent scholarship stresses the norms of fairness that miners employed in setting up basic rules especially with respect to maximum claim size, and the notions of fairness based on Lockean producerism and notice seem to have depended on striking the informational tradeoff in favor of stripped down communication for extensive audiences. ${ }^{95}$ It appears that one aspect of this process of mining customs becoming law is that miners who moved from one camp to another knew what to expect; the rules were formal (not heavily dependent on local community context), but could be bent among more consenting, closer-knit groups ${ }^{96}$ If miners' rules relied on their being focal, the more they confined themselves to what generally leads to salience, as opposed to highly local knowledge, the more effective they would be. ${ }^{97}$ Also, miners did not make up their norms out of whole cloth but selectively drew on general property norms and mining customs from earlier mines (e.g., lead), all of which is likely to make community custom easier to transmit to extensive audiences. As McDowell points out, miners did not know when they would be in the position of a new claimant and were therefore operating behind a veil of ignorance; ${ }^{98}$ furthermore, earlier claimants had an incentive to communicate their rules clearly to newcomers, which would require some formalization. ${ }^{99}$

$94 I d$. at 62.

95 On the process by which mining custom became law, see, for example, McDowell, supra note 28; David B. Schorr, Appropriation as Agrarianism: Distributive Justice in the Creation of Property Rights, 32 Ecology L.Q. 3 (2005); Zerbe \& Anderson, supra note 28.

96 McDowell, supra note 28, at 42-43.

97 Zerbe \& Anderson, supra note 28.

98 McDowell, supra note 28, at 6, 58-60.

99 Id. at 44 ("The miners clearly attempted to devise some clear, conspicuous form of notice that would indicate the boundaries of the claim and the name of its holder. 
How these rules were adopted into the common law (and later statutes) is sometimes implicit, but courts do articulate the process on occasion. For example, the Supreme Court of California, in a case about the notice required to locate a lode mining claim and in which a state statute directed courts to allow proof of customs respecting mining claims, had this to say about the process by which mining law developed:

At the time the foregoing became a part of the law of the land there had sprung up throughout the mining regions of the State local customs and usages by which persons engaged in mining pursuits were governed in the acquisition, use, forfeiture or loss of mining ground. . . . These customs differed in different localities and varied to a greater or less extent according to the character of the mines. They prescribed the acts by which the right to mine a particular piece of ground could be secured and its use and enjoyment continued and preserved and by what non-action on the part of the appropriator such right should become forfeited or lost and the ground become, as at first, publici juris and open to the appropriation of the next comer. They were few, plain and simple, and well understood by those with whom they originated. They were well adapted to secure the end designed to be accomplished, and were adequate to the judicial determination of all controversies touching mining rights. And it was a wise policy on the part of the Legislature not only not to supplant them by legislative enactments, but on the contrary to give them the additional weight of a legislative sanction. These usages and customs were the fruit of the times, and demanded by the necessities of communities who, though living under the common law, could find therein no clear and well defined rules for their guidance applicable to the new conditions by which they were surrounded, but were forced to depend upon remote analogies of doubtful application and unsatisfactory results. Having received the sanction of the Legislature, they have become as much a part of the law of the land as the common law itself, which was not adopted in a more solemn form. And it is to be regretted that the wisdom of the Legislature in thus leaving mining controversies to the arbitrament of mining laws has not always been seconded by the Courts and the legal

It was in every miner's interest to provide notice of his claim, to discourage others from working it, and to support his case if it was jumped and there was a dispute. But it was in the newcomer's interest that notice be required, so that a claim that was not clearly marked would be liable to be jumped."). 
profession, who seem to have been too long tied down to the treadmill of the common law to readily escape its thraldom while engaged in the solution of a mining controversy. These customs and usages have, in progress of time, become more general and uniform, and in their leading features are now the same throughout the mining regions of the State, and however it may have been heretofore, there is no reason why Judges or lawyers should wander, with counsel for the appellant in this case, back to the time when Abraham dug his well, or explore with them the law of agency or the Statute of Frauds in order to solve a simple question affecting a mining right, for a more convenient and equally legal solution can be found nearer home, in the "customs and usages of the bar or diggings embracing the claim" to which such right is asserted or denied. ${ }^{100}$

Here the court is defending a formalized version of custom against the general common law as the appropriate rule in a more extensive context, i.e., one that would apply to all miners, rather than only to those from one district, and potentially might apply to others who are not miners at all but belong to a wider community. At the very least the customs employed by the court are more standardized than are the original more local customs. And, to the extent that generalization involves stripping out local contextual information and spelling out the implicit, these more general customs are less information-intensive than the local community variety.

A particularly prominent and controversial example of the role of mining camp custom in the development of the law has been the doctrine of the pedis possessio, and its reception into the law may reflect the need to communicate in a more formal way with remote third parties. To have a valid unpatented mining claim (a property right less than a fee simple) under the General Mining Law of 1872, mining claimants must satisfy requirements of both location and discovery, and for rights against the United States both are essential. ${ }^{101}$ Nonetheless, a potential claimant is not just concerned about rights against the federal government, but would also be discouraged if third parties could jump his claim. Under the doctrine of pedis possessio, a miner has the right to exclusively work the spot he is currently working, even if he has not yet validly located a mineral claim. In its original version in the mining camps this custom gave an exclusive

100 Morton v. Solambo Copper Mining Co., 26 Cal. 527, 532-33 (1864) (emphasis added)

10130 U.S.C. $\S 23$ (2000). 
right to one working a spot against forcible, fraudulent, and clandestine intrusions, but the scope was the spot one was working, not the entire boundary of the unofficial claim. ${ }^{102}$ Under the original version of the pedis possessio, the "spot" involved was defined in terms of interference and was fuzzy as to its scope. ${ }^{103}$ When courts applied this rule they quickly expanded the area covered to the boundaries of the claim. ${ }^{104}$ The motivation for this was in part to provide greater protection for miners, but it is also consistent with greater ease of processing by outsiders. To such outsiders the boundaries of the claim are readily apparent, whereas the amount of land required for noninterference would be more subject to interpretation and dependent in part on local conditions and expectations.

Suggestive of the informational role of the claim boundary is the pull it exerts these days in the opposite direction. Despite a perceived need for greater scope of protection for uranium miners in the exploratory phase, courts have difficulty in extending the pedis possessio beyond the boundaries of a single claim. Currently mining for uranium requires selective exploration over a large area, and a custom of mutual noninterference has developed, but it is not legally enforceable, at least against non-agreeing parties. Without being clear on the source of law, the U.S. Supreme Court has held long ago that the pedis possessio does not apply to adjacent claims that are not being worked. A few courts have tried to expand the pedis possessio doctrine, but have drawn a great deal of criticism. ${ }^{105}$ Such courts can be seen as trying to incorporate a more recent custom. For example, for a wide pedis possessio (beyond a single claim that is actually being worked) the court in MacGuire v. Sturgis ${ }^{106}$ required similar geology and reasonable size, discovery work under state law, an overall work program, diligent pursuit of the work program, and economic impracticability if the narrow version of pedis possessio applied. ${ }^{107}$ These requirements are vague and presumably require knowledge of the local uranium mining industry. But uranium miners

102 Union Oil v. Smith, 249 U.S. 337 (1919).

103 See, e.g., William J. Forman, Robert G. Dwyer \& C. Robert Fox, Judicial Uncertainties in Applying the Mining Doctrine of "Pedis Possessio," 3 NAT. RESOURCES LAW. 467 (1970).

104 Field v. Grey, 25 P. 793, 794 (Ariz. 1881); Miller v. Chrisman, 73 P. 1083, 1086 (Cal. 1903), aff'd, 197 U.S. 313 (1905); James M. Finberg, The General Mining Law and the Doctrine of Pedis Possessio: The Case For Congressional Action, 49 U. CHI. L. REV. 1026, 1036 (1982).

105 MacGuire v. Sturgis, 347 F. Supp. 580 (D.C. Wyo. 1971); see also Continental Oil Co. v. Natrona Service, Inc., 588 F.2d 792, 798 (10th Cir. 1978).

106347 F. Supp. 580 (D.C. Wyo. 1971).

107 Id. at 584. 
in a given area will encounter miners from elsewhere and others who wish to use the land for different purposes. In the well-known case of Geomet Exploration, Limited v. Lucky Mc Uranium Corp. ${ }^{108}$ the court rejected the wider pedis possessio, limiting the doctrine to the bounds of a claim. This seems to be the mainstream approach and has the advantage of ease of communication to more extensive audiences. At various points in history the claim boundary seems to have exerted an expansive or constricting pull, in each case leading to a more formal version of pedis possessio than its customary analog.

\section{FURTHER IMPLICATIONS}

Custom plays an often underappreciated role within property law, in addition to its role as a separate system of social norms with purely private enforcement. This Part explores the implications of the information-cost theory of custom in the law for two key areas in property. First, because custom potentially makes informational demands on third parties, it is in tension with the numerus clausus. In civil law countries, those wishing to reform or abolish the numerus clausus tend to invoke custom as a source of law. Even in U.S. law, the courts' willingness to incorporate custom has led to tensions with even the weaker form of the numerus clausus characteristic of the common law. Second, in takings law, the longstanding problem of defining the baseline of entitlements against which regulations should be evaluated is potentially defined in part by custom. ${ }^{109}$

108601 P.2d 1339 (Ariz. 1979).

109 The baseline or background has long been a problem in takings. See, e.g., Lucas v. S.C. Coastal Comm'n, 505 U.S. 1003, 1029-30 (1992) (holding that regulations that prohibit all economically beneficial uses of land are takings if they prohibit uses not actionable under prior "background law" of property and nuisance); Richard A. Epstein, Takings, Exclusivity and Speech: The Legacy of PruneYard v. Robins, 64 U. CHI. L. REV. 21, 22-28 (1997) (arguing for common law nuisance as the baseline for takings law).

Custom and traditions should form part of the baseline for takings. See Carol M. Rose, Mahon Reconstructed: Why the Takings Issue Is Still a Muddle, 57 S. CAL. L. REV. 561, 598-99 (1984) (proposing that inquiry into property traditions will help uncover ordinary understandings that need takings protection and those that need to evolve). Nuisance is not the full sum of such a baseline but even nuisance itself is based in part on local custom. See Ellickson, supra note 3, at 728-33 (developing a theory of nuisance liability based on local community standards of behavior). 
The information-cost theory of custom in the law helps explain how custom is narrowed and formalized as part of that baseline.

\section{A. Property Customs and the Numerus Clausus Principle}

A large role for community custom in property law is in tension with the need for property to reach a large and indefinite audience of in rem duty-holders. This standardization is ensured in part by the numerus clausus principle, which limits the basic forms of property to a small closed set and channels major innovations in this list to legislatures. ${ }^{110}$ Wholesale adoption of community custom would make the list of property forms a potentially large and open-ended one. We have seen that courts, which themselves are in the position of outsiders, have a tendency to limit or to formalize customs before they can make it onto the constrained menu prescribed by the numerus clausus.

It is significant that historically the numerus clausus arose out of a concern about feudal custom. ${ }^{111}$ In the aftermath of the French Revolution, many feudal customs were removed from property law under the banner of the numerus clausus. What is sometimes taken these days to be a formalistic and conservative doctrine was at the beginning of its modern life a doctrine for the wholesale stripping of custom out of property law.

This tension between detailed custom and the numerus clausus is also reflected in the differing approaches to standardization in the common and civil law. Growing out of the post-French Revolution period and the Napoleonic codification, the civil law put a high premium on ex ante notice and a strong numerus clausus has always been one of its characteristics, especially in Germany. ${ }^{112}$ By contrast the common law usually adheres to a weaker form of the numerus clausus; until recently, indeed, the principle was mostly latent and did not even have a name. ${ }^{113}$ Correspondingly, the common law has been more welcoming to custom as a source of property law than have civil law systems. Some of the occasions on which the numerus clausus has been the weakest have involved custom. For example, in

110 Merrill \& Smith, supra note 39.

111 Id. at 7 n.15; see also ÉMILE ChÉNON, Les DÉMEMBREMENTS DE LA PropriÉTÉ FONCIÈRE EN FRANCE AVANT ET APRÈS LA RÉVOLUTION $§ 60$, at 91-183 (2d ed. 1923).

112 Merrill \& Smith, supra note 39, at 4-5, 9-12, 23-24.

113 Id. at 20-24; see also Bernard Rudden, Economic Theory v. Property Law: The Numerus Clausus Problem, in OXfORD EsSAYS IN JURISPRUDENCE 239 (John Eekelaar \& John Bell eds., 3d Series 1987). 
International News Service v. The Associated Press, ${ }^{114}$ the U.S. Supreme Court was willing to recognize a quasi-property right in hot news, and one rationale for the decision is that news organizations had such a custom in the first place. ${ }^{115}$ Indeed, if misappropriation and unfair competition are to be sources of new property rights, which is at least in tension with a strong numerus clausus, trade customs and morals are a prime source for the rights and duties. Nonetheless, the common law, despite some overenthusiastic statements by some theorists, does not adopt community custom wholesale but only moderately and in a simplifying fashion - consistent with the weak numerus clausus.

Interestingly, current debates over the numerus clausus in China, Japan, and Taiwan center on the role of custom. Those who would like to weaken or abolish the civil-law-style numerus clausus in those systems invoke the desirability of incorporating custom into property law. ${ }^{116}$ Overall, the historical and ongoing perceived tension between the numerus clausus and community custom confirms the importance of the information-cost issue highlighted in this Article.

\section{B. Custom and Property Baselines in Takings}

Custom plays a potentially important role in the law of regulatory takings. A perennial problem in takings law is how to define the baseline of entitlement against which a regulation's effect on the owner's property interest can be measured. Is a land-use regulation an exercise of the police power or the functional equivalent of an exercise of eminent domain?

In developing a series of per se rules that carve out classes of takings for special treatment, the U.S. Supreme Court seems to be influenced implicitly by the distinction between core and peripheral aspects of property. Thus, permanent physical invasions, even by a small cable box and wires, will count as a taking whereas much more intrusive regulations will not. ${ }^{117}$ This per se rule is like the law of trespass in that it does not make an exception for de minimis invasions. While one can argue whether such a de minimis exception would be desirable, a bright-line and over-inclusive rule based on

114248 U.S. 215 (1918).

115 See Epstein, supra note 6 (arguing for result in INS v. AP on the basis of prior custom).

116 See Yin Tian, Reflection on the Criticism of Numerus Clausus, 1 Front. L. CHINA 92, 94-95 (2006) (discussing and citing literature).

117 Loretto v. Teleprompter Manhattan CATV Corp., 458 U.S. 419 (1982). 
physical invasion is a first cut at land use conflict that does not rely heavily on local contextual information and is easy to communicate to the world at large. ${ }^{118}$

Nonetheless, the right to exclude by itself will not furnish a strong enough baseline. Regulations that do not lead to physical invasion may still "go[] too far." 119 On the other hand, if a restriction is longstanding enough, then the owner cannot complain that it is a taking, even if the regulation is very burdensome in terms of diminution of asset value. Likewise if the restriction prevents a harm that the owner never had a right to commit, the regulation does not effect a taking.

Most controversial in this regard was the attempt in Lucas v. South Carolina Coastal Council ${ }^{120}$ to fashion a per se rule for takings that wipe out all economic value. An exception to this per se rule was needed for regulations that aim at preventing uncontroversial harms. The opinion makes much reference to the law of nuisance: if a regulation prevents what would be a nuisance at common law, then the regulation is not a taking. ${ }^{121}$ The dissents and much commentary have criticized this use of nuisance law. First, nuisance law has always evolved and has not been the only source of change in property baselines, so that the question of whether a regulation is truly new is not an easy one. ${ }^{122}$ There is no reason to freeze the common law as of a particular date, and the majority in Lucas acknowledged the dynamic character of the nuisance exception. ${ }^{123}$ Second, a related matter, nuisance is

118 In the case of trespass, de minimis violations often happen without litigation. Whether a de minimis exception of some sort would track ordinary understanding and thus be simpler is a closer case than the use of physical invasions to pick out many cases for per se treatment. Although the Loretto result has come in for a large share of criticism, see, e.g., Michael A. Heller \& James E. Krier, Deterrence and Distribution in the Law of Takings, 112 HARV. L. REV. 997, 1007-09 (1999) (calling the per se rule for permanent physical invasions "passing strange" from the point of view of deterrence and distribution), viewing it as the analog of trespass and the extension to a new utility (cable television) of past practice (electricity, telephones) of using eminent domain makes it understandable as an exercise in rough simplicity. See MERRILL \& SMITH, supra note 69 , at $1297-98$.

119 Pennsylvania Coal Co. v. Mahon, 260 U.S. 393, 415 (1922).

120505 U.S. 1003 (1992).

121 See id. at 1031-32.

122 See id. at 1055 (Blackmun, J., dissenting); id. at 1068-70 (Stevens, J., dissenting).

123 See id. at 1031. 
notorious for being indeterminate. ${ }^{124}$ It has been termed a "'wilderness' of law," ${ }^{125}$ a "legal garbage can," ${ }^{126}$ and a "mystery." 127

The communicative tradeoff implicit in the choice of strategies for delineating property rights helps resolve this dilemma. It is quite understandable that takings law tends to invoke the law of nuisance. Nuisance law comes closest to incorporating the fine-grained detail of custom and yet it is semi-formalized into a format that courts can use. In other words, the law of nuisance, despite its faults, is appropriate for communication beyond communities while solving some of the micro-problems that the basic exclusion strategy does not. Although many have questioned why only the law of nuisance should play this mediating role between more informal norms and more formal law, it is an understandable starting point.

But nuisance is not likely to be the only governance scheme that forms the baseline of what the owner does and does not have in the default bundle of rights. Interestingly, some customs are important enough to register on the legal radar screen independently of their role in the law of nuisance. In those cases we might expect custom to form part of the property baseline in special high-stakes situations.

One such instance is the famous case of Miller v. Shoene, ${ }^{128}$ which involved a statute codifying a custom of favoring apple trees over cedar trees in the presence of a destructive fungus. Acting under the Cedar Rust Act of Virginia, the state entomologist ordered a number of appellant Miller's ornamental red cedar trees to be cut down. The statute allowed $\$ 100$ compensation for removal but did not compensate for the value of the trees or the decrease in the value of the land (but did allow the owner to use the trees as lumber). The statute provided for a procedure to consider requests for tree removal, including requests by officials and neighbors, and it applied to red cedars that

124 See, e.g., William W. Fisher III, The Trouble with Lucas, 45 StAN. L. REV. 1393, 1407 (1993) ("[W]hat is most striking about the holding of Lucas is that it embeds in the already muddy law of takings . . . the even muddier law of nuisance."); Michael C. Blumm \& Lucus Ritchie, Lucas's Unlikely Legacy: The Rise of Background Principles as Categorical Takings Defenses, 29 HARV. ENVTL. L. REV. 321, 323, 333-34, 367 (2005) (noting that contextual analysis in nuisance law is in tension with the categorical approach to takings in Lucas).

1251 H.G. WoOd, A Practical Treatise on THE LAW OF Nuisances in Their VARIOUS FORMS; INCLUDING REMEDIES THEREFORE AT LAW AND IN EQUITY, at iii (San Francisco, Bancroft-Whitney 3d ed. 1893).

126 William Prosser, Nuisance Without Fault, 20 TEX. L. REV. 399, 410 (1942).

127 Warren A. Seavey, Nuisance: Contributory Negligence and Other Mysteries, 65 HARV. L. REV. 984, 984 (1952).

128276 U.S. 272 (1928). 
the state entomologist determines to be the source of, harbor or constitute the host plant for the cedar rust, if the tree is within two miles of an apple orchard. Cedar-apple rust travels between cedars and apples and harms only the apples, which are an important commercial tree in Virginia, and which are far more valuable than the mostly ornamental cedars. Cedar owners received no benefits from controlling the parasite. The U.S. Supreme Court held that there was no taking. To reach this result it was not necessary to decide whether the keeping of the cedar trees was a nuisance.

The case has led to a number of very expansive interpretations. Legal Realists and their successors made much of language suggesting a skepticism about the public-private distinction: the state had to choose between the trees and is free to make this choice, here for the more valuable tree. ${ }^{129}$ Government doing nothing is the same as doing something, or, in the Court's words, "[i]t would have been none the less a choice if, instead of enacting the present statute, the state, by doing nothing, had permitted serious injury to the apple orchards within its borders to go on unchecked." ${ }^{130}$ The very same language has also been taken to have overtones of Coasean reciprocal causation. ${ }^{131}$ Neither tree owner, of cedar and apple respectively, can be said to cause the interaction more than the other. Indeed in this case the physical spores travel in both directions in their life cycle (the fungus is "heteroecious"), which undermines usual notions of causation that Coase criticized. ${ }^{132}$ The Coasean would see this as confirmation that invasions are not really important even in ordinary cases. Instead we have competing economic activities, one more valuable than the other, and the direction of an invasion by objects is simply irrelevant to the economic problem.

In an important article, William Fischel calls some of these interpretations into question. ${ }^{133}$ Instead of being "an effective new law of property," ${ }^{134}$ or even an exercise in Coasean nuisance-style balancing, that apple owners should prevail over the owners of rust-infested cedar trees was an established and

129 See, e.g., Louis M. SEIDMAN \& Mark V. Tushnet, Remnants of Belief: Contemporary Constitutional Issues 27 (1996); Warren Samuels, Interrelations Between Legal and Economic Processes, 14 J.L. \& ECON. 435 (1971); see also BARBARA H. FrIED, THE PROGRESSIVE ASSAULT ON LAISSEZ-FAIRE: ROBERT HALE AND THE FIRST LAW AND ECONOMICS MOVEMENT (1998).

130276 U.S. at 279.

131 William A. Fischel, The Law and Economics of Cedar-Apple Rust: State Action and Just Compensation in Miller v. Shoene, 3 REV. L. \& ECON. 133, 149-51 (2007).

$132 I d$.

133 Id.

134 Samuels, supra note 129 , at 438-39. 
well-known custom. The ability of the state to choose the more valuable use was uncontroversial (not a breakdown of the public-private distinction) and the lack of compensation responded to moral hazard concerns (opportunistic claims by owners of cedars that were more valuable cut than standing). Apple orchard owners usually paid to have cedars removed consensually and usually did not invoke the law. Even after this case, cedar owners were compensated for disruption to farming operations and incidental damage to land. Fischel concludes that the case was rightly decided but the dictum that the government could have decided the opposite was wrong; it would have been unthinkable even to the cedar owners. The lead plaintiff in the case, Dr. Casper Otto Miller, even voted for the 1914 law which passed 88-0 during his one term in the Virginia House of Delegates. There was a baseline that was commonly understood for this type of dispute - causation is not reciprocal. Common law nuisance is not the only source of traditional understandings and baselines.

Custom is part of the baseline defining owners' rights, but what is that custom? Fischel offers a somewhat expansive version of the custom in the background of Miller v. Shoene, as being one of "prices make rights." ${ }^{135} \mathrm{In}$ a conflict between conflicting commercial crops, the more valuable one wins. This is a very general but very vague custom. Instead I suggest that the custom was simply about cedars and apple trees, and related high-profile conflicts between commercial species led to similar specific customs (e.g., barberry and wheat). Fischel is right that the content of the custom is based on tree value and that such a custom is not limited to these two trees, but in communicating the custom more widely, the custom benefited from the fact that this cedar-apple rust problem was well known in the state of Virginia. It is unlikely that such a custom would be applied wherever one could find a commercial conflict on an individualized basis, and indeed even on Fischel's formulations it appears that in his other cases of "prices make rights" the winning species has to be vastly more valuable than the losing one (as was the case with apples and cedars), again making the custom easier to communicate. The degree of conflict required and the valuation would make a general legalized custom of prices-make-rights difficult to apply. (In related fashion, in the law of nuisance, simple balancing of the worth of two activities is not the sum total of the analysis: it is both more and less than that and relies on invasions of boundaries more than is often portrayed. ${ }^{136}$ ) A custom of "prices make rights" would also have to incorporate all the cost-effective mitigation mechanisms

135 Fischel, supra note 131, at 156.

136 Smith, supra note 43, at 990-1007. 
that might be applicable in other as yet unspecified conflicts. Instead, the cedar-apple custom appears to be a specific one in the context of high stakes. But it is a narrow and formal one: apple trees win in the cedar-apple-rust context. Even the statutory version of the custom is fairly bright-line. It makes little effort to distinguish between cedar trees or degree of infestation, etc. Whatever the proper level of specificity of the custom(s) involved in the case, Fischel's study makes it clear that the custom, as a commonsense solution to a familiar problem, was a widely shared nonlegal norm. ${ }^{137}$ As such, it did not present great informational burdens to third parties and was already part of the property baseline.

\section{Conclusion}

Community customs present a communicative problem when the custom presumes more than the type of general knowledge common beyond the confines of its community. In order for the customs of particular communities to be suitable for use beyond the modular communities in which they arise, the communicative tradeoff - of intensive, informationrich messages versus reaching extensive audiences - needs to be restruck. Either communication will be more costly for these remote third parties, or the custom must be formalized, i.e., made less dependent on the community context. Judges and juries largely lack community knowledge, and the process of proving a custom and filtering it through doctrines requiring "certainty" with a view toward "generality" has the effect of adaptation through formalization. Famous episodes of property customs such as mining and whaling seem to conform to this pattern.

137 Fischel, supra note 131, at 189. 
